\title{
Tumor Necrosis Factor Alpha-Induced Protein 2
}

National Cancer Institute

\section{Source}

National Cancer Institute. Tumor Necrosis Factor Alpha-Induced Protein 2. NCI

Thesaurus. Code C120977.

Tumor necrosis factor alpha-induced protein 2 ( $654 \mathrm{aa}, \sim 73 \mathrm{kDa}$ ) is encoded by the human TNFAIP2 gene. This protein may be involved in the regulation of both inflammation and angiogenesis. 